\title{
EFFICIENCY OF BACILLUS SUBTILIS AND PSEUDOMONAS FLUORESCENCE AS BIOCONTROL AGENTS AGAINST RHIZOCTONIA SOLANI ON SPEARMINT PLANTS (MENTHA VIRIDIS L.)
}

\author{
Ebtsam, M. Morsy ${ }^{*}$ and Nadia, A.M. El-Said ${ }^{* *}$ \\ * Soils, Water and Environment Research Institute ARC, Giza, Egypt. \\ ** Horticulture Research Institute ARC, Giza, Egypt.
}

\begin{abstract}
The effect of Bacillus subtilis and Pseudomonas fluorescence as biocontrol agent against Rhizoctonia solani on Mentha viridis L. plants was evaluated. The pot experiment was conducted during two successive seasons (2012 and 2013) in the Experimental Farm of Medicinal and Aromatic Plants Research Department in El Kanater El Khairia. Sex treatments were conducted, Control (without any treatments), $R$. solani (infested pathogenic fungi), $R$. solani + fungicide (Vitavax T. 0.15\%), R. solani + Bacillus. subtilis (B.S), R. solani + Pseudomonas. fluorescence (Ps.f) and $R$. solani + B.s + Ps.f (combination of the two bioagents).

The results showed that the highest decrease in percentage of infected plants, the increment of the survival plants percentage and the activity of dehydrogenase enzyme were recorded with the plants infested with B. subtilis, Ps. fluorescence individually and the combination treatment in comparison to the control and $R$. solani infested plants at both cuts in both seasons. Moreover, the highest values of growth parameters (plant height, number of branches, plant fresh and dry weight) as well as volatile oil percentage were recorded with the same treatments. The most effective treatment was the dual application treatment (B. s and Ps. f) which gave the highest volatile oil yield/plant in both cuts during the two seasons. While the volatile oil main component (Carvone) recorded maximum values 62.20 and $61.34 \%$ in case of R. solani + B. subtilis and the dual treatment.
\end{abstract}

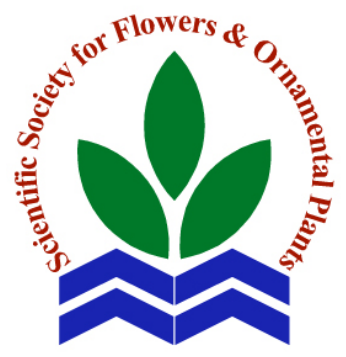

Scientific J. Flowers \& Ornamental Plants, 2(3):213-225 (2015).

Received:

$30 / 11 / 2015$

Revised by:

Prof. Dr. M.S. Hanafy, Cairo Univ.

Prof. Dr. A.M. Hammouda, Hort. Res. Inst., ARC.

Key words: Mentha viridis, Spearmint, Bacillus subtilis, Pseudomonas fluorescence, Biocontrol agents, Rhizoctonia solani.

\section{INTRODUCTION}

Mentha species (commonly known as mint), belongings to family Lamiaceae, constitute one of the most popular essential oil crops. They are widely distributed and cultivated in the temperate and subtemperate regions of the world, Dorman et al (2003). Also Lawrence et al., (1992) mentioned that, genus Mentha consist of more than 25 species and are well known for monoterpenes like menthol, menthone, carvone and pulegone. Phenolic acids, flavonoids, terpenoids and volatile compounds have been identified as the major compounds found in different extracts of mint Choudhury et al. (2006). Mentha viridis essential oil rich in carvone (50.47\%), 1,8cineole $(9.14 \%)$, and limonene $(4.87 \%)$ Mkaddem et al. (2009).

Some mint species have received attention as preventive medicines since they have beneficial health effects, such as 
antioxidant and antibacterial activity, Mimica-Dukić et al. ( 2003) and Gulluce et al. (2007). They are widely used by food and pharmaceutical industries as a flavor or in fragrance formulations. Mentha spp. have been used as a folk remedy for treatment bronchitis, flatulence, anorexia, ulcerative colitis and liver complaints due to their antiinflammatory, carminative, antiemetic, diaphoretic, antispasmodic, analgesic, stimulant, and anticatharral activities, Gulluce et al. (2007).

The host range of Rhizoctonia solani is wide and it causes various diseases on important crop plants of the world including vegetables, fruits, ornamental, medicinal and aromatic plants such as spearmint plants. $R$. solani is the main causal agent of dampingoff disease of seedlings as well as root and stem rot in young transplants of several plant species. Damping off occurs when seeds or young seedlings are attacked by these pathogens. Seeds attacked by these fungi usually fail to germinate. Seedlings can be damaged in two ways: the roots may rot causing the seedling to wilt and quickly die, or the seedling may be attacked on the stem at the ground line, causing the seedling to collapse (Subash et al., 2013).

The infection process is promoted by the production of many extracellular enzymes that degrade various components of plant cell walls such as chitinases, pectinases and xylanases. These components are activated the pathogens to start and grow inter and intracellular degrading the tissue, which can be seen as necrotic lesions on epidermal tissue of shoots, roots or as damping off of the young seedlings (Jayasinghe et al., 2004).

Application of the fungicides is not economical and not safe in both short and long time because they pollute the environment, leave harmful residues and can lead to the development of resistant strains of the pathogen with repeated use. Therefore the use of biocontrol agents is an alternative, eco-friendly approach treatment for control of plant pathogens, produce safety food and reduce the environment pollution (Vinale et al., 2008).

The antagonistic micro-organisms such as Bacillus and Pseudomonas effectively protect plants from soil borne pathogens such as $R$. solani (Gaebeva et al., 2004). These micro-organisms can produce direct or indirect effects on host plants. Indirect effects are those related to the production of metabolites, such as antibiotics, siderophores or hydrogen cyanide which increase plant growth by decreasing the activities of pathogens or deleterious micro-organisms. Direct effect on plant growth by producing metabolites such as plant growth regulators that direct promote plant growth or by facilitating nutrient uptake and enhancement of seedling emergence rates (Morsy, 2005).

The aim of this study was to evaluate efficiency of Bacillus subtilis and Pseudomonas fluorescence as a biocontrol agents against Rhizoctonia solani on plant growth yield and active ingredients of Mentha varidis plants.

\section{MATERIALS AND METHODS}

\section{Isolation of pathogenic fungi:}

Rhizoctonia solani was isolated from root rot spearmint infected plants which were cultivated in pots (May 2011). It was identified on the basis of cultural and microscopic characteristics. Pathogenicity of the isolate on spearmint plant was estimated according to Sneh et al. (1991). Isolate was maintained on PDA medium at $4{ }^{\circ} \mathrm{C}$.

\section{Biocontrol agents:}

Bacillus subtilis and Pseudomonas fluorescens were kindly provided from Microbiology Department, Soils, Water and Environment research institute, (ARC), Giza, Egypt.

\section{In-vitro assay:}

Bacterial strains were tested for their quantitative capabilities to produce auxins according to Glickmann and Dessoux (1995) and gibberellins according to the method of Udagwa and Kinoshita (1961). While 
siderophores and hydrogen cyanide were qualitative determined according to Alexander and Zuberer (1991) and Bakker and Schippers (1987), respectively.

Moreover these bacterial strains were tested for their antagonistic activity against pathogenic fungi $R$. solani according to the method described by Silo-Suh et al. (1994). The growth and reduction in mycelial growth of the pathogenic fungi was calculated according to Fokemma (1973).

\section{Preparation of pathogenic fungal inocula:}

Corn meal-sand medium (3:1, w/w) were autoclaved in $500 \mathrm{ml}$ glass bottles at $121{ }^{\circ} \mathrm{C}$ for $20 \mathrm{~min}$. The sterilized bottles were then inoculated with disks $(5 \mathrm{~mm})$ of 7 days old culture of $R$. solani and incubated at $25 \pm 1{ }^{\circ} \mathrm{C}$ for 15 days.

\section{Preparation of bacterial inocula:}

Conical flasks $(250 \mathrm{ml})$ containing 100 $\mathrm{ml}$ of King's broth medium (King et al., 1954) or nutrient glucose broth medium (Difco, 1984) were sterilized at $121^{\circ} \mathrm{C}$ for 15 min were used as growth media. The flasks were inoculated with a loop- full of the tested strains (Pseudomonas and Bacillus, respectively) then incubated at $28-30^{\circ} \mathrm{C}$ on rotary shaker $(150 \mathrm{rpm})$ for 2 days. Bacterial strains standardized to $1 \times 10^{7} \mathrm{CFU} / \mathrm{ml}$ for inoculating pathogenic fungi infested soil.

\section{Pots experiment:}

The pots were conducted in the Experimental Farm of Medicinal and Aromatic Plants Research Department in El Kanater El Khairia to evaluate the potentialities of these strains for the biocontrol of $R$. solani during two successive seasons (2012 and 2013). The pots were sterilized with $5 \%$ formalin solution and left to dry before use. Also, sterilized soil were placed in every pot $(30 \mathrm{~cm}$ diameter $)$ and were artificially infested by $R$. solani standard inoculate at the rate of $5 \%$. The infested soils were irrigated daily for one week before planting to enhance growth and distribution of the inocula. Spearmint seedlings (12-15 cm in height, with 10-12 leaves) were obtained from the Farm of Medicinal and Aromatic Plants Research Department in El-Kanater El-Khairia and transplanted in the pots (one plant/pot). Sex treatments were conducted as follow:

1. Control (without any treatments).

2. R. solani (infested pathogenic fungi).

3. R. solani + fungicide (Vitavax $\mathrm{T}$. $0.15 \%)$.

4. R. solani + Bacillus. subtilis (B.s).

5. R. solani + Pseudomonas fluorescence (Ps.f).

6. R. solani + B.s + Ps.f (combination of the two bioagents).

Three replicates were specified for each treatment (every replicate consisted of 10 pots) in completely randomized experimental design.

Plants in all experiments received the recommended chemical fertilizers and the normal agricultural practices of irrigation and weeding.

Spearmint seedlings were treated by drenching $10 \mathrm{ml}$ from each bacterial suspension $\left(1 \times 10^{7} \mathrm{CFU} / \mathrm{ml}\right)$ of $B$. subtilis and $P$ s. fluorescence to each pot individually or in combined mixture (1:1) after, 15 and 30 days from transplanting.

Plant infection of root rot and the percentage of healthy survival plants were recorded after two month from transplanting. After each cut, total microbial counts was estimated by decimal dilution plat count technique on nutrient agar medium. Dehydrogenase enzyme activity was also determined after each cut (Skujins 1976).

Spearmint plants were harvested twice, the $1^{\text {st }}$ cut was conducted in Jun 15 and the $2^{\text {nd }}$ one in September 15 in the two seasons. Growth parameters i.e. plant height $(\mathrm{cm})$, number of branches/plant, herb fresh and dry weights (g/plant) were recorded. The percentage of volatile oil in fresh herb (calculated as dry weight) determined by hydrodistillation for $3 \mathrm{~h}$ using a Clevenger- 
type apparatus according to Guenther (1961). Some samples were taken from the volatile oil of the $2^{\text {nd }}$ cut in the $2^{\text {nd }}$ season $R$. solani, $R$. solani + B. subtilis (B.s), R. solani + Ps. fluorescence (Ps.f) and R. solani + (B.s + Ps.f) treatments) and analyzed using gas liquid chromatography (GLC) analysis to determine their main constituents. The use of GLC in the quantitative determinations was performed using the method described by Bunzen et al. (1969) and Hoftman (1967).

Statistical analysis was made using a software package "Costat," a product of cohort software Inc. Berkley, California. The significance of various treatments was evaluated at a probability level of 0.05 as illustrated by Snedecor and Cochran (1980).

\section{RESULTS AND DISCUSSION}

In-vitro Effect of bacterial strains as a biocontrol of $R$. solani and phytohormones producer:

Bacterial strains were tested in vitro for their abilities to antagonize $R$. solani the causative agent of spearmint plants root rot disease. In addition, their activities to produce auxins and gibberellins as a plant growth promoting substances as well as siderophores and hydrogen cyanide suppressing plant pathogen were determined.

Data presented in Table (1) showed that the tested bacterial strains succeeded to reduce radial growth of the pathogenic fungus. The strain of Ps. fluorescens was most effective which gave $50 \%$ reduction followed by B. subtilis (42.2\%). Moreover these strains have the ability to secrete siderophores and hydrogen cyanide. In regard to hormones production, the strain of Ps. fluorescens was superior to B. subtilis where it produced $109.5 \mu \mathrm{g} / \mathrm{ml}$ of auxins. In contrary, B. subtilis strain overtook the Ps. fluorescens in gibberellins production where, it produced $120.9 \mu \mathrm{g} / \mathrm{ml}$.

These results were in agreement with Tuzun and Klopper (1994) and Morsy et al. (2009) who reported that different plant growth promoting rhizobacteria (PGPR) which can able to suppressing soil borne plant pathogens by different mechanisms, including the production of secondary metabolites such as antibiotics, cyanide and siderophore, which were mediated competition on the available iron and carbon as well as induction of plant disease resistance. In other words, Siderophores and hydrogen cyanide have a key role in the biocontrol against soil borne phytopathogen, beside the essential function of siderophores in improvement of iron nutrition (Dobbelaere et al., 2003).

\section{Effect of biological control agents individually or in combination on infection and survival percentage of spearmint plants:}

Data listed in Table (2) demonstrated the effect of two bacterial strains on percentage of root infection and survival of spearmint seedlings over two successive seasons. The two bacterial strains gave significant reduction in the percentage of infected seedlings and dead plants due to root rot and wilt. Moreover, a significant increase of healthy survival plants over control was recorded. Whereas, the dual inoculation with (B.s and Ps.f) has the highest significant decrease in the percentage of the infected plants and increase of the percentage of survival plants $(81 \%$ for the first season and $84 \%$ for the second season) comparing with the individual application. These results could be attributed to the synergistic effect of the combination between the two microorganisms in this treatment.

Competition between pathogens and non-pathogens for nutrient resources is important for limiting disease incidence and severity. The most abundant non-pathogenic plant associated microbes are generally thought to protect the plant by rapid colonization and there by exhausting the limited available substrates so that none are available for pathogens to growth, Compant et al. (2005) and Van loon (2007). It has been found that the reduction in disease incidence must be due to competition 
Table 1. In-vitro Effect of bacterial biocontrol of $\boldsymbol{R}$. solani production of phytohormones, siderophores and hydrogen cyanide.

\begin{tabular}{lcccccc}
\hline \multicolumn{1}{c}{ Strains } & $\begin{array}{c}\text { Radial } \\
\text { growth } \\
(\mathbf{c m})\end{array}$ & $\begin{array}{c}\text { Reduction } \\
(\mathbf{\%})\end{array}$ & Siderophores & $\begin{array}{c}\text { Hydrogen } \\
\mathbf{c y a n i d}\end{array}$ & $\begin{array}{c}\text { Auxins } \\
\boldsymbol{\mu g} / \mathbf{m l}\end{array}$ & $\begin{array}{c}\text { Gibberellins } \\
\boldsymbol{\mu g} / \mathbf{m l}\end{array}$ \\
\hline Control & 9.0 & 0.0 & - & - & - & - \\
Bacillus subtilis & 5.2 & 42.2 & + & + & 75.2 & 120.9 \\
Ps. fluorescence & 4.5 & 50 & + & + & 109.5 & 40.1 \\
\hline
\end{tabular}

Table 2. Effect of biological control agents individually or in combination on infection and survival percentage of spearmint plants.

\begin{tabular}{|c|c|c|c|c|c|}
\hline \multirow[b]{2}{*}{ Treatments } & \multicolumn{2}{|c|}{ First season (2012) } & \multicolumn{3}{|c|}{ Second season (2013) } \\
\hline & Infection & (\%) Survival & Infection & $(\%)$ & Survival \\
\hline Control & 35 & 65 & 37 & & 63 \\
\hline R. solani & 90 & 10 & 92 & & 12 \\
\hline R. solani + Fungicide & 10 & 90 & 9 & & 91 \\
\hline R. solani + B. subtilis (B.s) & 25 & 75 & 23 & & 77 \\
\hline R. solani + Ps. fluorescence (Ps.f) & 22 & 78 & 21 & & 79 \\
\hline R. solani $+($ B.s + Ps. f) & 19 & 81 & 16 & & 84 \\
\hline LSD 0.05 & & 2.516 & & 2.813 & \\
\hline
\end{tabular}

between PGPR and pathogenic fungi or production of siderophores and hydrogen cyanide which resulted in limiting the growth of the pathogens.

Effect of biological control agents individually or in combination on dehydrogenase activity and total microbial count of spearmint rhizosphere:

Dehydrogenase activity and total microbial counts were recorded after two cuts in the two seasons Table (3). Fungicide treatment (vitavax) gave low values of dehydrogenase enzyme activity and total microbial counts due to the fungicide antimicrobial activity against the microbial population in the rhizosphere. Whereas, the significant increase in the dehydrogenase enzyme activity was found with microbial treatments especially the dual application with (B.s + Ps.f) after each cut in the two seasons compared with control. Results of dehydrogenase activity confirmed those of total microbial flora and could be considered as an additional proof for higher microbial activity in spearmint plant rhizosphere in response to inoculation with the tested strains.
Dehydrogenase enzyme has been considered as a sensitive indicator of soil quality and it has been proposed as a valid biomarker to indicate changes in total microbial activity due to changes in soil management. The increase in dehydrogenase activity as a result of soil inoculation with antagonistic bacteria may be due to the phytohormones especially auxins that secreted by B. subtilis, Ps. fluorescence and their combination (Table 1) in comparison with control at the harvest time (full bloom). Dehydrogenase is an oxidoreductase, which is only present in viable cells. The value of dehydrogenase activity and total microbial flora counts of various treatments were higher at the flowering stage than the vegetative one. This difference could be attributed to the qualitative and quantitative changes in the nature and root exudates during growth stages (Morsy et al., 2009).

Effect of biological control agents individually or in combination on vegetative growth parameters of spearmint plants:

Data presented in Table (4) showed that the lowest values of growth parameters (plant height, number of branches, plant 
Table 3. Effect of biological control agents individually or in combination on dehydrogenase activity and total microbial count of spearmint rhizosphere.

\section{First season (2012) Second season (2013)}

\begin{tabular}{|c|c|c|c|c|c|c|c|c|}
\hline \multirow[t]{2}{*}{ Treatments } & \multicolumn{2}{|c|}{$\begin{array}{c}\text { Dehydrogenase } \\
\text { activity }(\mu \mathrm{g} \\
\text { TPF/g dry } \\
\text { soil/day) }\end{array}$} & \multicolumn{2}{|c|}{$\begin{array}{c}\text { Total microbial } \\
\text { count } \\
\left(\text { CFU } \times 10^{6} / g\right. \\
\text { rhizosphere) }\end{array}$} & \multicolumn{2}{|c|}{$\begin{array}{c}\text { Dehydrogenase } \\
\text { activity ( } \mu \mathrm{g} \\
\text { TPF/g dry } \\
\text { soil/day) }\end{array}$} & \multicolumn{2}{|c|}{$\begin{array}{l}\text { Total microbial } \\
\text { count } \\
\left(\mathrm{CFU} \times 10^{6} / \mathrm{g}\right. \\
\text { rhizosphere) }\end{array}$} \\
\hline & $1^{\text {st }}$ cut & $2^{\text {nd }}$ cut & $1^{\text {st }}$ cut & $2^{\text {nd }}$ cut & $1^{\text {st }}$ cut & $2^{\text {nd }}$ cut & $1^{\text {st }}$ cut & $2^{\text {nd }}$ cut \\
\hline Control & 27.1 & 45.6 & 13.0 & 18.0 & 30.2 & 51.3 & 17.0 & 21.0 \\
\hline R. solani & 20.6 & 32.5 & 11.0 & 20.0 & 23.3 & 37. & 12.0 & 23.0 \\
\hline R. solani + Fungicide & 33.8 & 49.2 & 23.0 & 35.3 & 37.2 & 54.4 & 27.1 & 40.5 \\
\hline R. solani + B. subtilis (B.s) & 46.5 & 70.9 & 40.0 & 49.0 & 51.5 & 82.3 & 46.0 & 53.0 \\
\hline R. solani + Ps. fluorescence & 60.2 & 81.1 & 49.0 & 65.3 & 66.7 & 94.5 & 55.0 & 71.3 \\
\hline R. solani + (B.s + Ps. f) & 69.6 & 93.2 & 56.0 & 84.6 & 75.4 & 105.3 & 62.2 & 94.7 \\
\hline LSD 0.05 & 2.722 & 4.818 & & & 3.328 & 5.79 & & \\
\hline
\end{tabular}

Table 4. Effect of biological control agents individually or in combination on vegetative growth parameters of spearmint plants.

\begin{tabular}{|c|c|c|c|c|c|c|c|c|}
\hline \multirow{3}{*}{ Treatments } & \multicolumn{8}{|c|}{ First season (2012) } \\
\hline & \multicolumn{2}{|c|}{ Plant height(cm) } & \multicolumn{2}{|c|}{$\begin{array}{c}\text { Number of } \\
\text { branches/plant }\end{array}$} & \multicolumn{2}{|c|}{$\begin{array}{l}\text { Fresh weight } \\
\text { (g/plant) }\end{array}$} & \multicolumn{2}{|c|}{$\begin{array}{l}\text { Dry weight } \\
\text { (g/plant) }\end{array}$} \\
\hline & $1^{\text {st }}$ cut & $2^{\text {nd }}$ cut & $1^{\text {st }}$ cut & $2^{\text {nd }}$ cut & $1^{\text {st }}$ cut & $2^{\text {nd }}$ cut & $1^{\text {st }}$ cut & $2^{\text {nd }}$ cut \\
\hline Control & 32.0 & 19.7 & 21.7 & 13.7 & 27.3 & 11.3 & 13.5 & 5.6 \\
\hline R. solani & 35.0 & 23.0 & 35.0 & 19.7 & 50.7 & 22.0 & 25.0 & 10.8 \\
\hline R. solani + Fungicide & 40.7 & 28.3 & 47.3 & 28.7 & 60.2 & 25.1 & 29.6 & 12.3 \\
\hline R. solani + B. subtilis (B.s) & 47.0 & 33.3 & 46.3 & 42.3 & 84.4 & 82.1 & 41.8 & 40.7 \\
\hline R. solani + Ps. Fluorescence (Ps.f) & 50.0 & 37.7 & 53.0 & 42.7 & 108.1 & 81.3 & 54.1 & 40.7 \\
\hline R. solani + (B.s + Ps.f) & 40.7 & 38.0 & 54.7 & 38.7 & 109.6 & 53.0 & 54.8 & 38.2 \\
\hline \multirow[t]{2}{*}{ LSD 0.05} & 2.69 & 0.84 & 8.13 & 3.08 & 13.59 & 4.84 & 6.75 & 2.40 \\
\hline & \multicolumn{8}{|c|}{ Second season (2013) } \\
\hline Control & 35.0 & 23.0 & 24.7 & 19.0 & 33.3 & 14.5 & 16.4 & 7.2 \\
\hline R. solani & 40.7 & 25.0 & 45.3 & 20.7 & 58.0 & 30.2 & 28.5 & 14.9 \\
\hline R. solani + Fungicide & 47.7 & 30.3 & 48.7 & 29.7 & 74.3 & 34.3 & 36.5 & 16.9 \\
\hline R. solani + B. subtilis (B.s) & 53.3 & 36.0 & 47.3 & 45.0 & 99.1 & 94.1 & 49.1 & 46.7 \\
\hline R. solani + Ps. Fluorescence (Ps.f) & 60.7 & 39.0 & 59.0 & 46.7 & 127.1 & 85.2 & 63.5 & 42.6 \\
\hline R. solani + (B.s + Ps.f) & 45.0 & 39.7 & 56.7 & 49.7 & 139.5 & 83.5 & 69.8 & 41.7 \\
\hline LSD 0.05 & 2.45 & 0.94 & 3.82 & 2.94 & 5.54 & 5.17 & 2.75 & 2.57 \\
\hline
\end{tabular}

fresh and dry weights) were recorded with the control plants and $R$. solani treatments in both cuts in the two seasons in comparison with the rest treatments. Whereas the significant increases in different growth parameters were correlated with the dual application treatment (B. subtilis $+P S$. fluorescence) compared with the individual ones during the growth season.

The results listed in Table (4) showed that an increase of plant height $(\mathrm{cm})$ in response to all treatments was recorded in the first and second cut during the two seasons. This increment was significant compared to control plants. The spearmint plants treated with $B$. subtilis and $P S$. fluorescens individual or mixed showed a promotion in growth in term of plant elongation. The increase of plant height $(50.0$ and $60.7 \mathrm{~cm})$ were observed with the individual treatment of Ps. fluorescens in the first cut at the first and second season, respectively. While, the highest significant increase in spearmint plant height was recorded with combined treatment (B.s + Ps.f) which reached to 38.0 and $39.7 \mathrm{~cm}$ at the second cut in both seasons, respectively. 
Concerning the number of branches, the inoculation with the combined treatment and Ps. fluorescens solely in first and second cuts in the first season gave significant increase in number of branches, 54.7 and 42.7 branches/ plant, respectively. Moreover, in the second season, the Ps. fluorescens treatment recorded the highest significant increase 59.0 branches/ plant in first cut while the combined treatment was the best in second cut (49.7 branches/ plant).

The fresh weight of spearmint herb (g/plant) was also affected as a result of different application of bacterial bioagents. The obtained data showed significant increase in fresh weight of plant herb of all treatments compared with control and R. solani, respectively. The combined treatment (B.s + Ps.f) recorded the highest increase in herb fresh weight $(109.6 \mathrm{~g} / \mathrm{plant})$ in first cut but $\mathrm{B}$. subtilis treatment recorded the highest increase $82.1 \mathrm{~g} / \mathrm{plant}$ in the second cut in the first season. The same trend was found in the second season with these treatments, they gave 139.5 and $94.1 \mathrm{~g} / \mathrm{plant}$ at first and second cuts, respectively.

With respect to the values of herb dry weight, all the studied treatments were also positively affected by different applied bacterial bioagents. The highest values of herb dry weights in spearmint plants were 54.8 and $69.8 \mathrm{~g} /$ plant in the first cut in both seasons as a result of the application of the combined treatment. The application of the individual treatment either with B. subtilis or Ps. fluorescens gave the same record at the second cut of the first season (40.7 g/plant). Meanwhile the highest value of herb dry weight (46.7 g/plant) was noticed with the solely treatment of $B$. subtilis in the second cut of second season. It could be noticed that, the promotion of plant growth in term of herb fresh weight due to the bioegent treatment led to an increase in herb dry weight, so, the highest values of herb dry weights were generally associated with the highest values of branches number and herb fresh weight.
The increase of plant growth could be attributed to the aforementioned role of both micro-organisms that secreted phytohormones as well as sidrophores and hydrogen cyanide. The promotion of spearmint growth parameters by B. subtilis and/or Ps. fluorescence strains may due to their abilities to produce phytohormones, vitamins and solubilizing minerals beside their role in direct inhibition of pathogen growth Morsy et al. (2009). In the same way data in Table (1) which demonstrated the phytohormones analysis it could be concluded that spearmint plant growth was positively affected by the hormonal balance of Ps. fluorescens treatment consequently growth was found to stimulated in response to this treatment, these results agreed those of Tilak et al. (2005) who reported that B. subtilis and/or Ps. fluorescence may associated with the plant rhizosphere and they able to exert a beneficial effect on plant growth.

Effect of biological control agents individually or in combination on volatile oil percentage $(\%)$ and volatile oil yield (ml/plant) of spearmint plants:

Regarding the oil productivity, results in Table (5) showed that, percentage of volatile oil and oil yield were significantly higher in spearmint plants inoculated with different treatments in comparison with control. In both seasons, the treatment with $B$. subtilis was more effictive in volatile oil production at first cut, it gives 1.12 and $1.13 \%$, in the first and second season respectively. Whereas in the second cut, the combined treatment (B.s + Ps.f) was the best one which gives the same values $(1.48 \%)$ at the two seasons.

With respect to volatile oil yield $\mathrm{ml} /$ plant, the control gave the lowest values at the two cuts in both seasons. While under the influence of the individual treatments $B$. subtilis or Ps. fluorescens plants produced volatile oil yield with significant increase compared to the control at both cuts in both seasons. The combined treatment was the 
Table 5. Effect of biological control agents individually or in combination on volatile oil percentage $(\%)$ and volatile oil yield $(\mathrm{ml} /$ plant) of spearmint plants.

\begin{tabular}{|c|c|c|c|c|c|c|c|c|}
\hline \multirow{3}{*}{ Treatments } & \multicolumn{4}{|c|}{ First season (2012) } & \multicolumn{4}{|c|}{ Second season (2013) } \\
\hline & \multicolumn{2}{|c|}{$\begin{array}{c}\text { Volatile oil } \\
(\%)\end{array}$} & \multicolumn{2}{|c|}{$\begin{array}{l}\text { Volatile oil yield } \\
\text { (ml/plant) }\end{array}$} & \multicolumn{2}{|c|}{$\begin{array}{c}\text { Volatile oil } \\
\text { (\%) }\end{array}$} & \multicolumn{2}{|c|}{$\begin{array}{l}\text { Volatile oil yield } \\
\text { (ml/plant) }\end{array}$} \\
\hline & $1^{\text {st }}$ cut & $2^{\text {nd }}$ cut & $1^{\text {st }}$ cut & $2^{\text {nd }}$ cut & $1^{\text {st }}$ cut & $2^{\text {nd }}$ cut & $1^{\text {st }}$ cut & $2^{\text {nd }}$ cut \\
\hline Control & 0.81 & 1.18 & 0.11 & 0.070 & 0.82 & 1.18 & 0.14 & 0.08 \\
\hline R. solani & 0.84 & 1.25 & 0.21 & 0.140 & 0.89 & 1.24 & 0.26 & 0.183 \\
\hline R. solani + Fungicide & 0.87 & 1.1 & 0.26 & 0.140 & 0.93 & 1.10 & 0.34 & 0.181 \\
\hline R. solani + B. subtilis (B.s) & 1.12 & 1.02 & 0.47 & 0.420 & 1.13 & 1.09 & 0.56 & 0.510 \\
\hline R. solani + Ps. Fluorescence (Ps.f) & 0.92 & 1.3 & 0.50 & 0.530 & 0.96 & 1.42 & 0.61 & 0.603 \\
\hline R. solani $+($ B.s + Ps.f) & 0.97 & 1.48 & 0.53 & 0.570 & 1.00 & 1.48 & 0.69 & 0.620 \\
\hline LSD 0.05 & 0.06 & 0.02 & 0.08 & 0.03 & 0.06 & 0.02 & 0.05 & 0.03 \\
\hline
\end{tabular}

unique one and gave the highest volatile oil yield in both cuts during the two seasons.

The increase in yield parameters and oil yield not only due to the reduction in disease incidence but also due to the production of phytohormon by PGPR, which improved plant growth. In this investigation the obtained results indicated that the tested strains of PGPR produced auxins and gibberellins Table (1) affected mint plants growth, these findings were found to be in harmony with those of (Salme 2003 and Badawi et al., 2007).

Effect of biological control agents individually or in combination on percentage of volatile oil constituents of spearmint in $2^{\text {nd }}$ Season $\left(2^{\text {nd }}\right.$ cut $)$ :

The GLC analysis were carried out on the volatile oil of spearmint herb for 4 treatments in the second cut of the second season, which were, R. solani, $R$. solani $+B$. subtilis (B.s), R. solani + Ps. fluorescence (Ps.f) and R. solani + (B.s+ Ps.f).

Data recorded in Table (6) and figures (1-4) showed volatile oil constituents of spearmint herb. The major constituents of the volatile oil (Carvone) was influenced by bacterial application either individual or in combination. Carvone content increased from $57.88 \%$ in $R$. solani treatment to 61.34 and 62.20 under the influence of the combined application and the individual one $R$. solani $+B$. subtilis application, respectively. The second main component D-
Limonene showed different response in this respect, its values were slightly increase in response to PS. fluorescence while it decreased in the rest treatment compared to $R$. solani one. This behavior may be explained on the light of carvone content as it increased dependent on D-Limonene content and vice versa.

\section{RECOMMENDATION}

It could be recommended to use Bacillus subtilis and Pseudomonas fluorescence as biocontrol against Rhizoctonia solani to reduce the use of fungicide as well as environment pollution.In addition to obtain the highest growth and volatile oil yield as well as the highest volatile oil quality of spearmint plants.

\section{REFERENCES}

Alexander, D.B. and Zuberer, D.A. (1991). Use of chrome azurol $S$ reagents to evaluate siderophore production by rhizosphere bacteria. Biol. Fertil. Soils, 12:39-45.

Badawi, F.Sh.F.; Shehata, H.Sh.; Mekhemar, G.A.A. and Mazen, M.M. (2007). Biological control of chickpea wilt disease caused by Fusarium oxysporum $\mathrm{f}$ sp ciceris by using some rhizobacteria. N. Egypt. J. Microbiol., 16(1):98-117.

Bakker, A.W. and schippers, B. (1987). Microbial cyanide production on the rhizosphere in relation to potato yield reduction and Pseudomonas spp. Mediated plant growth-stimulation. Soil Biol. Biochem., 19:451-457. 
Table 6. Effect of biological control agents individually or in combination on volatile oil constituents (\%) of spearmint plants in $2^{\text {nd }}$ Season $\left(2^{\text {nd }}\right.$ cut $)$.

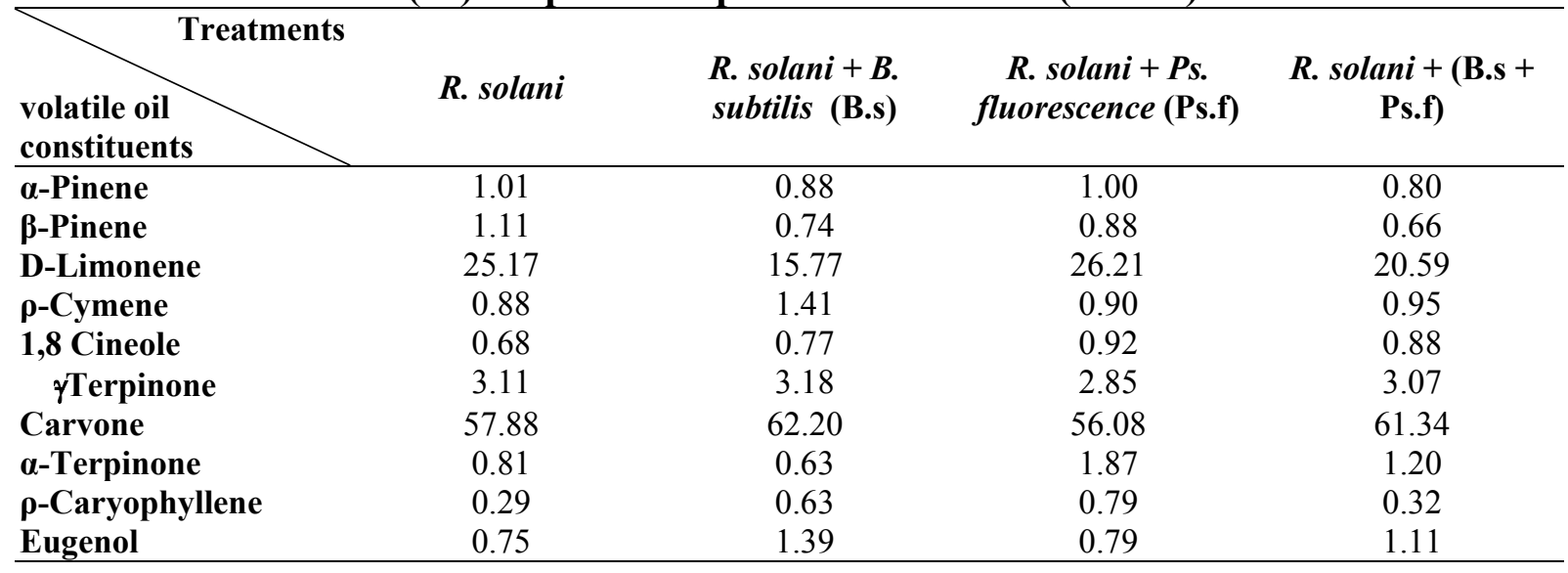

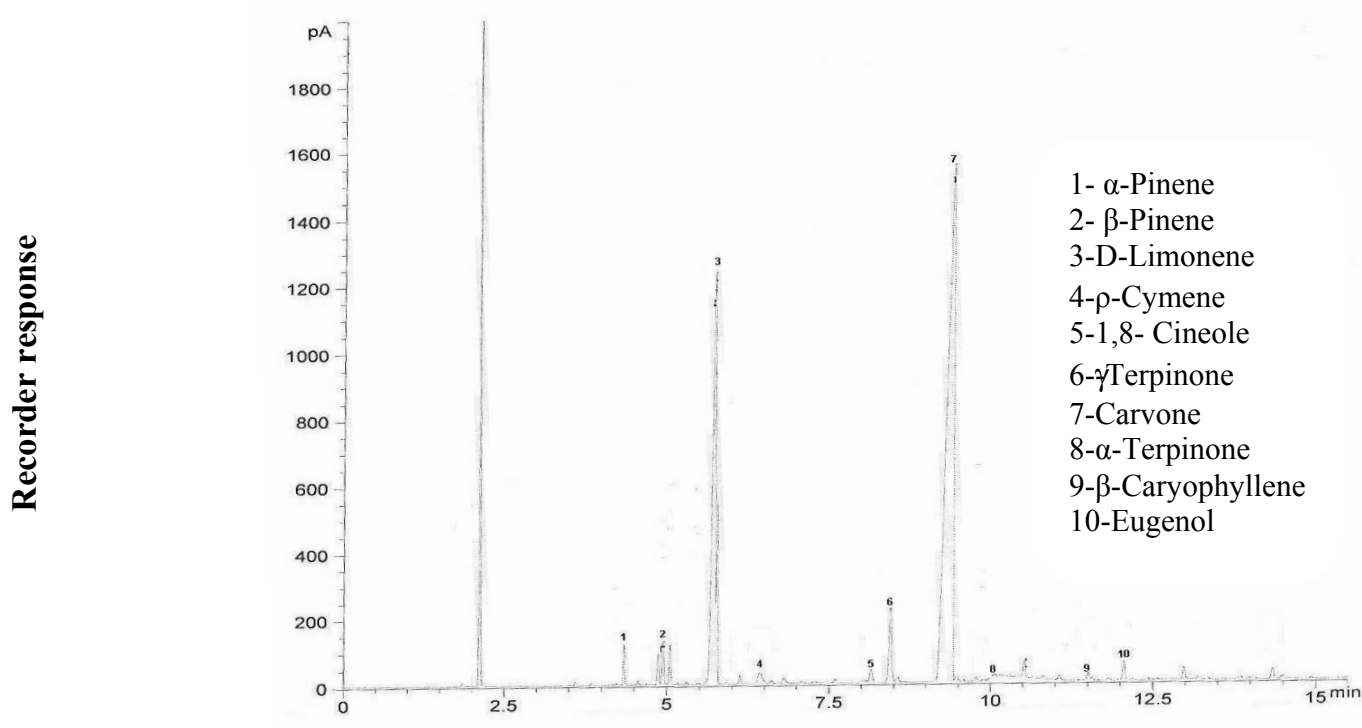

Retention time (min)

Fig. 1. Volatile oil constituents of spearmint plants without infection and treatment (control). 


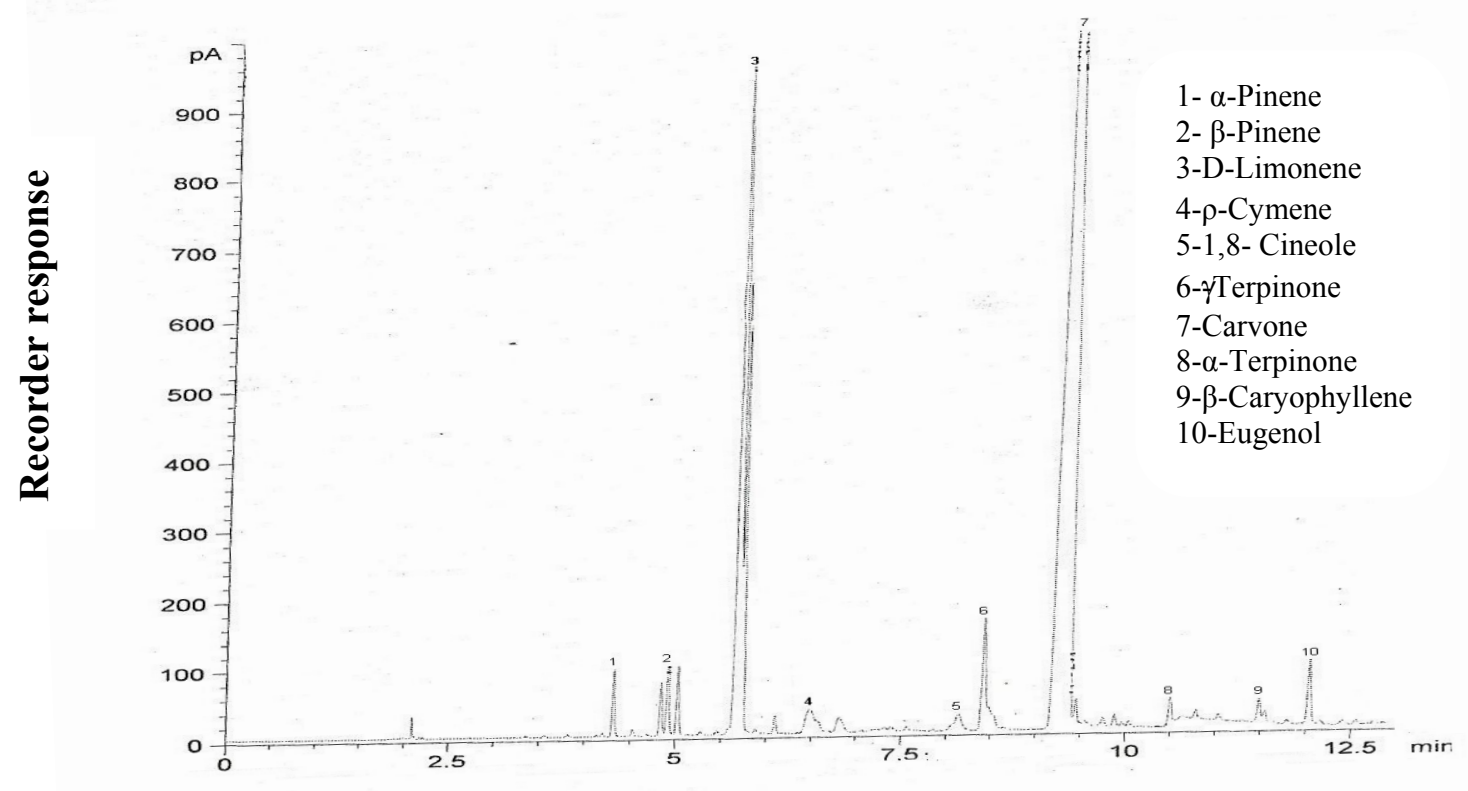

Retention time (min)

Fig. 2. Volatile oil constituents of spearmint plants as affected by (R. solani + B. subtilis (B.s)).

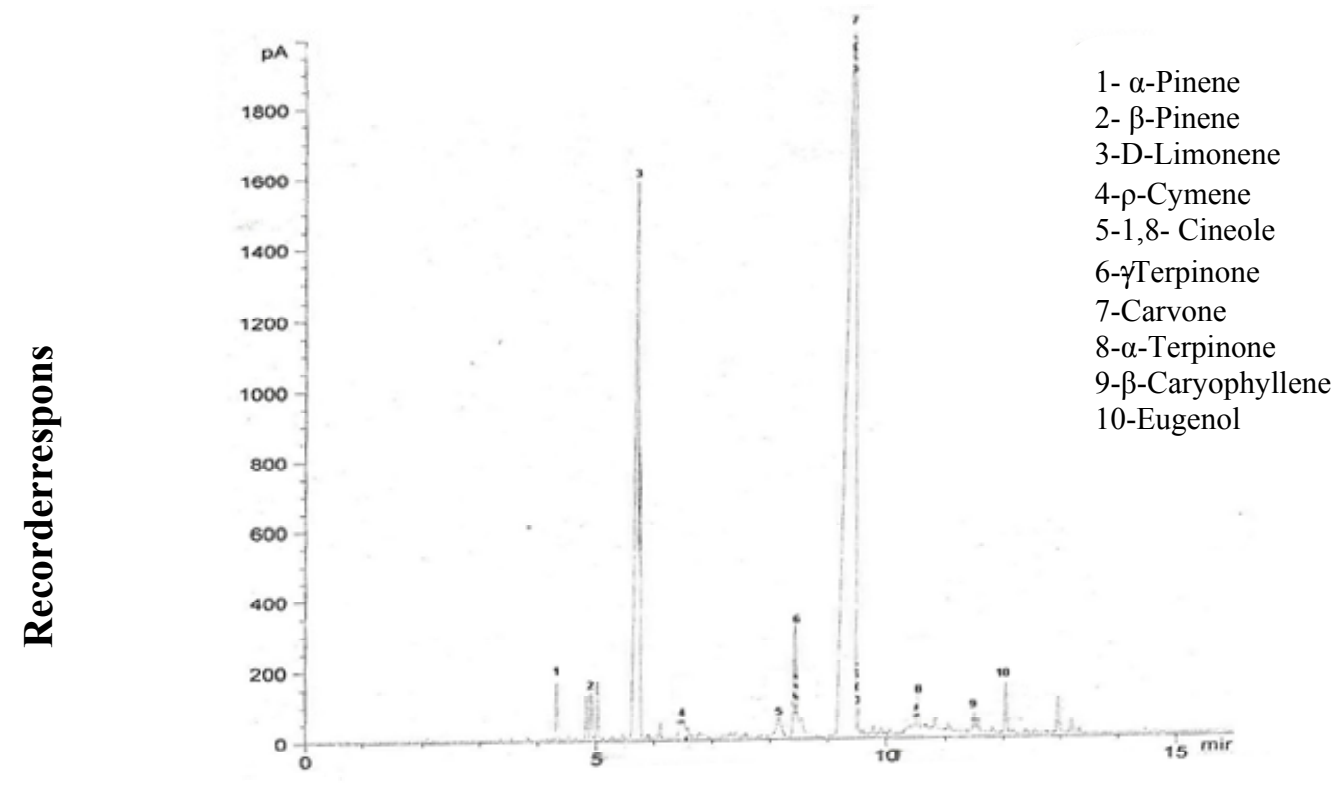

Retention time (min)

Fig. 3. Volatile oil constituents of spearmint plants as affected by (R. solani $+P S$. fluorescence (Ps.f). 


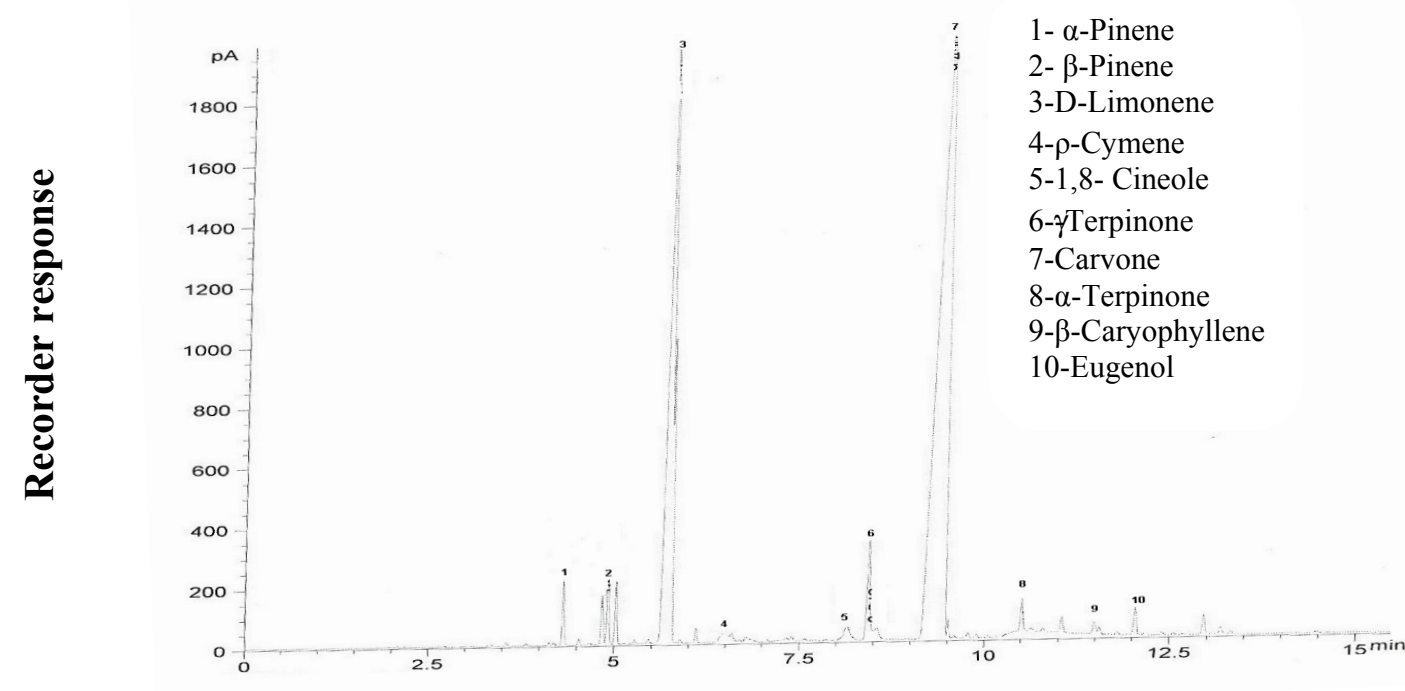

Retention time (min)

Fig. 4. Volatile oil constituents of spearmint plants as affected by (R.solani + B.s. + Ps. f. $)$.

Bunzen, J.N.; Guichard, J.; Labble, P.; Prevot, J. and Trenchant, J. (1969). Partical Manual of Gas Chromatography. J. Trenchant Ed. El. Seiviet. Publ. Comp. Amst. London. 38-44.

Choudhury, R.P.; Kumar, A. and Garg, A.N. (2006). Analysis of Indian (Mentha spicata) for essential, trace and toxic elements and its antioxidant behaviour. Journal Pharmaceutical and Biomedical Analysis, 41:825-32.

Compant, S.; Duffy, B.; Nowak, j.; Clement, C. and Barka, E.A. (2005). Use of plant growth -promoting bacteria for biocontrol of plant diseases: Principles, mechanisms of action, and future prospect. Appl. and Env. Microbiology., 7(9):491-495.

Difco Manual. (1984). Dehydrated culture media and reagents for microbiology. Laboratories incorporated Detroit. Michigan, 48232 USA. p.1027.

Dobbelaere, S.; Vanderleyden, J. and Okon, Y. (2003). Plant growth-promoting effects of diazotrophs in the rhizosphere. Critical Reviews in Plant Sciences, 22: 107-149.

Dorman, H. J.; Kosar, M.; Kahlos, K.; Holm, Y. and Hiltunen, R. (2003). Antioxidant properties and composition of aqueous extracts from Mentha species, hybrids, varieties, and cultivars. J. Agric. Food Chem., 51: 4563-4569.

Fokemma, N.J. (1973). The role of saprophytic fungi in antagonism against Derchslera sorokaniana (Helminthosporium sativum) on agar plates and on rye leaves with pollen. Physiol. Plant Pathol., 3: 195-205.

Gaebeva, P.; Van Veen, J.A. and Van Elsas, J.D. (2004). Microbial diversity in soil: selection of microbial population by plant and soil type and implications for disease suppressiveness. Annu. Rev. Phytopathol., 42:243-270.

Glickmann, E. and Dessoux, Y. (1995). A critical examination of specificity of the Salokowski reagent for indolic compounds produced by 
phytopathogenic. Appl. Environ. Microbiol., 61:793-796.

Guenther, E. (1961): The Essential oils. Vol (1), van Nostrand Co., New York.

Gulluce. M.; Sahin, F.; Sokmen, M.; Ozer, H.; Daferera, D.; Sokmen, A.; Polissiou, M.; Adiguzel, A. and Ozkan, H. (2007). Antimicrobial and antioxidant properties of the essential oils and methanol extract from Mentha longifolia L. ssp. Longifolia. Food Chemistry 103:14491456.

Hoftman, E.(1967). Chromatography .Reeinhold .publ.crop $2^{\text {nd }}$ ed.,pp. 208515.

Jayasinghe, C.K.; Wijayaratne, S.C.P. and Fernando, T.H.P.S. (2004). Characterization of cell wall degrading enzymes of Thanatephorus cucumeris. Mycopathologia, 157:73-79.

King, E.O.; Ward, M.K. and Raney, D.E. (1954). Two simple media for the demonstration of pyocyanin and flourescein. J. Lab. Clin. Med.44: 301307.

Lawrence, B.M. In: Harly R.M., Reynard T., eds.(1992). Advances in Labiate. Kew: Royal Botanic Gardens., 399-436

Mkaddem, M.; Bouajila, J.; Ennajar, M.; Lebrihi, A.; Mathieu, F. and Romdhane, M. (2009). Chemical composition and antimicrobial and antioxidant activities of Mentha longifolia $\mathrm{L}$. and viridis essential oils. J. Food Sci., 74(7):358-63.

Mimica-Dukić N, Bozin B, Soković M, Mihajlović B and Matavulj M. (2003). Antimicrobial and antioxidant activities of three Mentha species essential oils. Plant Medicinal, v.69, p.413-9.

Morsy, Ebtsam, M. (2005). Role of growth promoting substances producing microorganisms on tomato plant and control of some Root Rot fungi. Ph.D. Thesis, Fac. of Agric. Ain shams Univ., Cairo.
Morsy, E.M.; Abdel-Kawi, K.A. and Khalil, M.N.A. (2009). Efficiency of Trichoderma viride and Bacillus subtilis as biocontrol agents against Fusarium solani on tomato plants. Egypt J. Phytopathol., 37(1):47-57.

Salme, T. (2003). Mechanism of action of the plant growth promoting bacterium Paenibacillus polymyxa. ACTA Universttatis Upsalien, UPPSALA (PDF).

Silo-Suh, L. A.; Lethbridge, B. J.; Raffel, S. J.; He, H.; Clardy, J. and Handelsman, J. (1994). Biological activities of two fungistatic antibiotics produced by Bacillus cereus UW85. Appl. Environ. Microbiol. 60: 2023-2030.

Skujins, J. (1976). Extracellular enzymes in soil. CRC Crit. Rev. Microbiol., 4: 383 421.

Snedecor, G. W. and G. W. Cochran (1980). Statistical Methods. $7^{\text {th }}$ Edn, Iowa State Univ. Press, Ames, USA. Sneh, B.; Burpee, L. and Ogosh. A. (1991): Identification of Rhizoctonia species. The American Phytopathological Society. St. Paul, Minnesota, USA. Pp.133.

Subash, N.; Meenakshisundarm, M. and Sasikumar, C. (2013). In-vitro evaluation of different strains of Trichoderma harzianum as bio-control agents of chilli. Intl. J. Biol., Pharma. Allied Sci., 2(2): 495-500.

Tilak, K.V.; Ranganayaki, N.; Pal, K.K.; De, R.; Saxena, A.K.; Nautiyal, C.S.; Mittal, S.; Tripathi, A.K. and Johri, B.N. (2005). Diversity of plant growth and soil health supporting bacteria. Curr. Sci., 89(1):136-150.

Tuzun, S., and Kloepper, J.W. (1994). Induced systemic resistance by plant growth-promoting rhizobacteria. In: Improving Plant Productivity with Rhizosphere Bacteria. M.H. Ryder, P.M. Stephens, and G.D. Bowen, eds. CSIRO, Adelaide, South Australia, Australia, 104-109. 
Udagwa, K. and Kinoshita, S. (1961). A colorimetric determination of gibberellic acid. J. Agric. Chem. Soc. Japan, 35: 219-223.

Van loon, L.C. (2007). Plant responses to plant growth-promoting rhizobacteria. Eur. J. Plant Pathol., 119: 243-254.
Vinale, F.; Sivasithamparam, K.; Ghisalberti, E.L.; Marra, R.S.L. and Lorito, M. (2008). Trichoderma - plant pathogens interactions. Soil Biology and Biochemistry, 40:1-10.

\section{كفاءة فacillus subtilis and Pseudomonas fluorescence فى المقاومة الحيوية ضد Rhizoctonia solani

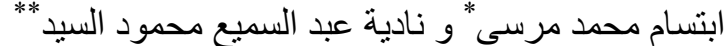

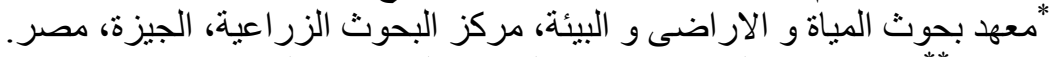

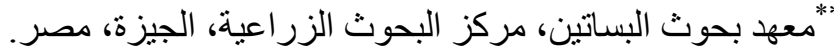

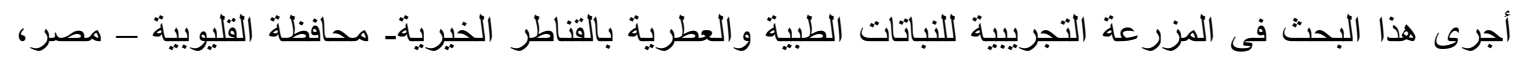

خلال موسمين (reudomonas و Bacillus subtilis Rhizoctonia solani المسبب لعفن الجذورفى نبات النعناع البلدى. fluorescence

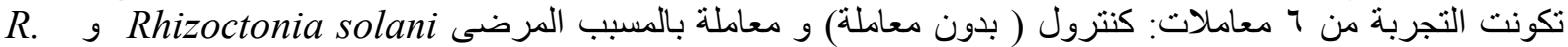

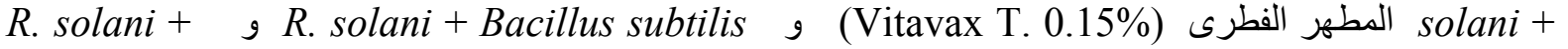
. Pseudomonas fluorescence + Bacillus subtilis) و و مخلوط منهمات Pseudomonas fluorescence

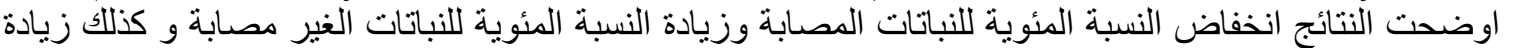

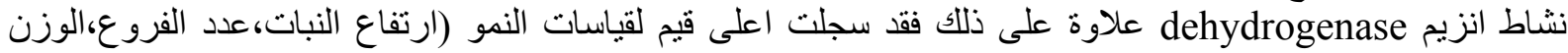

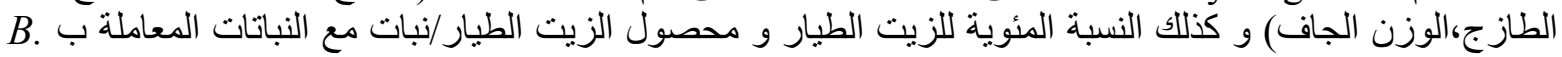

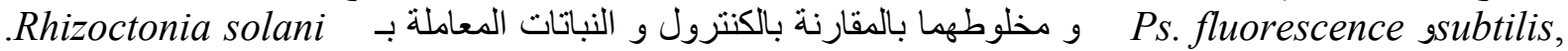

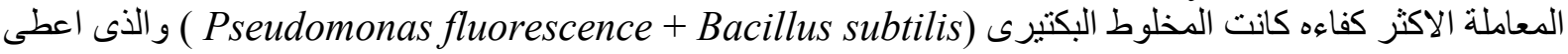

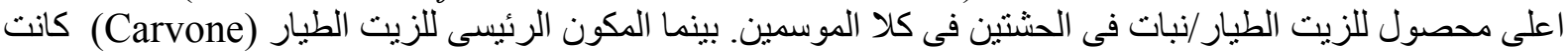

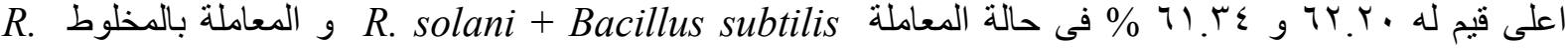
.(Bacillus subtilis + Pseudomonas fluorescence) solani + 


